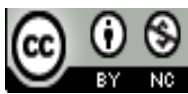 \\ Journal Terapan Manajemen dan Bisnis is licensed under \\ A Creative Commons Attribution-NonCommercial 4.0 International License
}

\title{
Educational Empowerment in Managing Means and Infrastructure on Faculty of Teacher Training and Education (FKIP) at Tanjungpura University
}

\author{
M. Chiar \\ Fakultas Keguruan dan Ilmu Pendidikan, Universitas Tanjungpura, Indonesia \\ E-mail: chiarfkip@gmail.com
}

\begin{abstract}
Empowerment is the giving of strength to individuals or groups to be more empowered than before and has a responsibility in exercising the authority entrusted to them. Therefore, empowerment is essential for an institution as a form of enormous internal power contributing to the institution. With the empowerment, institutions are increasingly responsive to change, renewal science, and technology, especially in the field of education which continues to grow following the demands of the times. This research focuses on empowering education personnel in managing facilities and infrastructure at the Teacher Training and Education Faculty. The focus of this study is "How is the empowerment of educational staff in managing facilities and infrastructure at the Teacher Training and Education Faculty?". Based on the focus of the research, the research problems are detailed as follows: 1 . What is the planning of empowering education personnel in managing facilities and infrastructure? 2. How is the implementation of the empowerment of education staff in managing facilities and infrastructure?. 3 What are the steps taken by the faculty leaders in empowering education personnel? 4. How is the evaluation of the empowerment of education personnel in managing facilities and infrastructure? 5. What are the factors that support and inhibit empowering communities against the revitalization of education?

This study uses a descriptive method with a qualitative approach. The data collection tools used were interviews, observation and documentation guidelines. Based on the results of the study, it was found that empowerment planning was carried out by a team that had been formed to create a program based on the faculty's vision and mission. In implementing the empowerment of education staff the leaders coordinated, but on the other hand, the methods used to optimize work were still conventional. Evaluation of the empowerment of education personnel is carried out still by manual process, including the reporting system: The supporting factors include; Availability of internet access and utilization of technology for monitoring. Openness in planning to evaluation. The participation of all faculties in ensuring the optimization of education staff. Dedication and totality of education staff, especially team who have been assigned for more than five years in FKIP. While the inhibiting factors include: The flow of institutional planning and organization at the university which is considered too long (less simple), most monitoring and evaluation systems still use manuals, but online (modern) reporting and evaluation systems are being prepared. Central government policies related to the procurement of facilities and infrastructure that must be submitted a maximum of two years earlier. All activities need to be planned with good predictions so that challenges for HR (Human Resources) planning. The absence of performance monitoring technology, such as CCTV as a support tool for staff control in managing facilities and infrastructure.
\end{abstract}

Keywords: Infrastructure; educational empowerment; education 


\section{Introduction}

The meaning of empowerment in this study is the giving of strength to individuals or groups to be more empowered than before and have a responsibility in exercising the authority entrusted to them. Therefore, empowerment is crucial for an institution as a tremendous form of internal power contributing to the institution.

Empowering means empowering those who are powerless and/or developing the power they already have into something more useful, especially for specific communities and organizations. An institution/organization that has implemented empowerment will experience changes quickly and be able to compete with other institutions. Cristensen and Robinson (1984) reveal that empowerment is a personal and social process. Empowerment implies the liberation of individual ability, competition, creativity, and freedom of action while empowering implies giving a wave of strength from one person to another and also from within, especially the power to act and develop to become something called Paolo Freire namely " more humanizing humans ".

The Teacher Training and Education Faculty (FKIP) is the only Educational Personnel Education Institution (LPTK) at Tanjungpura University that manages facilities and infrastructure, both academic and non-academic facilities. In this institution many have educational staff, both honorary and civil servants.

These educational staff have their respective duties and one of their tasks is to manage the facilities and infrastructure in FKIP. With regard to that facilities and infrastructure need to be managed optimally so that special education can be utilized. Efforts to empower educational staff can be seen from three sides: First, creating an atmosphere or climate that enables potential employees to develop. Empowerment is an effort to improve that power, by encouraging, motivating and raising awareness of its potential and trying to develop it. Second, strengthen the potential or power possessed by employees. This strengthening includes concrete steps and involves providing various inputs. Third, empowering also means protecting

This research focuses on empowering education personnel in managing facilities and infrastructure at the Teacher Training and Education Faculty. The reason for choosing at the Teacher Training and Education Faculty is because of the uniqueness of this institution, so it is interesting to study. This institution is interesting to study because it has the most students compared to other faculties at Tanjungpura University. With a large number of students, it will also affect the management of facilities and infrastructure as supporting facilities. Therefore, it takes education staff who can manage facilities and infrastructure.

The intended management of facilities and infrastructure is to utilize material or infrastructure resources optimally which in turn can contribute to the learning process. Based on the description above, the Teacher Training and Education Faculty as an Educational Institution of Education which is the only faculty under the Tanjungpura University environment is worthy of investigation. The focus of this research is "What is the management of empowerment of education personnel in managing facilities and infrastructure at the Teacher Training and Education Faculty?" Based on the focus of this study, the research problem was formulated as follows: How is the implementation and steps of empowering education personnel in managing facilities and infrastructure? How is the evaluation of the empowerment of education personnel in managing facilities and infrastructure? What are the factors that support and inhibit empowering communities against the revitalization of education?.

In general, the objectives to be achieved in this study are to describe the management of empowerment of education personnel in managing facilities and infrastructure at the Teacher Training and Education Faculty. In particular, this study aims to obtain information about: Planning empowerment of education personnel in managing facilities and infrastructure, Implementation and steps of empowering education personnel in managing facilities and infrastructure, Evaluating the 
empowerment of education personnel in managing facilities and infrastructure, Factors that support and hamper the empowerment of education personnel in managing facilities and infrastructure.

The benefits in this study are as follows: Theoretically the results of this study are useful to provide useful contributions, both methodologically and empirically for academic interests in the science of education management, especially in the field of management of empowerment of education personnel. Practically the results of this study are useful to be used as information material for education managers in an effort to improve and develop the performance of education personnel, both those who are still in honor and those who have been appointed as civil servants.

\section{Literature review}

Empowerment

In the conventional sense, the concept of empowerment has two meanings. First, to give power or authority to or give power, divert power, or delegate authority to another party. Second, to give ability to or to enable or an effort to provide knowledge or empowerment. (Wrihatnolo and Dwidjowijoto, 2007: 115). Robert Adam (2003; 8) defines empowerment as "the means by which individuals, groups and communities can achieve their own goals, there are by being able to work towards themselves and others to maximize the quality of their lives".

Meanwhile Ruth Alsop et al $(2006 ; 1)$ defines empowerment as "the process of enhancing an individual's or group's capacity to make purposive choices and to transform those choices into desired actions and outcomes". Jacqueline B. Mondros and Scott M. Wilson (1994: 228) defines: "Empowerment, we believe, is a psychological state, a sense of competence, control and entitlement that allows people to pursue concrete activities aimed at becoming powerful".

Based on several opinions above, it can be synthesized several important elements in carrying out an empowerment. (a) Empowerment is a business that emphasizes the process of giving some authority or ability to individuals, communities or organizations to be more empowered. (b) Empowerment is done to maximize, increase capacity or increase the potential of individuals or organizations as effectively as possible. (c) Empowerment fosters independence and a sense of responsibility in individuals in an organization.

The Khan empowerment model, as shown in Figure 1, is divided into six stages, namely desire (trust), trust (trust), confident (confidence), credibility (credibility), accountability (authority), and communication (communication). Sequentially. The following is an explanation of the six stages of the Khan empowerment model: Desire (Desire): The first stage in the empowerment model is the desire that arises from management to provide opportunities or involve subordinates to identify developing problems. Trust: after the management wishes to do empowerment, the next step is to build trust between management and employees or assistants. The existence of mutual trust between members of the organization will create right conditions for the exchange of information and advice. Confident (self-confidence): Self-confidence raises mutual trust among employees by respecting the abilities possessed by employees. Credibility (credibility): Maintaining credibility with appreciation and develop a work environment that encourages healthy competencies so that organizations that have high performance are created. Accountability (authority): the next step in the empowerment process is the accountability of employees or subordinates to the authority that has been given. By setting consistently and clearly about the roles, standards, and objectives of the assessment of the performance of employees in the settlement and responsibility for the authority given.6. Communication (communication): Communication is openness that is useful for creating mutual understanding between employees and management. This openness can be realized through criticism and suggestions on the results and achievements of the workers. The purpose of empowering education personnel is basically to improve the effectiveness of the organization's work, where through this empowerment process employees have the freedom to carry out their duties and 
responsibilities. Professional educators and education staff are the determinants of the quality education process. Effective management of education personnel in Indonesia must be seen that the development of education personnel is part of national development. An overall HR development, as well as seeing the relationship of various influential components. According to Glickman (2002: 2), said that:

"These successfully schools typically have no greater amounts of time or success than those where this scenario is a pipe dream,but the difference is have time,focus, and structure are used; how staff development, school agreement, personnel evaluation, and classroom assistants are used together;and how instructional leadership is defined and employed".

\section{Methodology}

Starting from the focus of the problem, the purpose of the study, the research subject and the characteristics of the data to be collected, the type chosen is development research with a qualitative approach. The research will be conducted at the Faculty of Teacher Training and Education at Tanjungpura University Pontianak. The selection of the Teaching and Education Faculty as a place of research because it has the most students and achievers. FKIP is the only National Education Workforce Institution in Tanjungpura University Pontianak.

In addition to the faculty leaders, data sources were also obtained from education staff, both those who were civil servants and those who were still laborers. The procedure for collecting data in this study was carried out by: interviews, namely the faculty leaders, among others, the deputy dean, head of administration, head of sub-equipment, informatics, and civil servants and honorary employees. This interview was conducted intensively and repeatedly to the respondents so that the data obtained was better and more accurate. 2. Conduct observations by systematically recording the visible symptoms. 3. Through documentation that is collecting written data, images related to research problems. Data obtained from interviews and field notes were analyzed qualitatively. Data analysis techniques in this study were carried out through data reduction, data display, and verification processes. The validity of the findings in the study was conducted by validating the empowerment model carried out by the faculty leaders. Therefore, in-depth observations, triangulation, literature review, document review, and tracking the suitability of the results with related elements. Before conducting research, it is necessary to schedule the following stages:

1. Preparation phase: preparation of proposals, initial discussion, assessment in the field, selection of informants, and preparation of guiding instruments.

2. The field activity stage researchers immediately jump into the field to collect data through observation, interviews and documentation of data sources

3. The final stage is collecting data, completing data, classifying data, then proceeding to improve the empowerment model of the education staff

\section{Result and Discussion}

1. Planning

Broadly speaking, the preparatory steps in managing education personnel to manage facilities and infrastructure within FKIP are carried out through several stages, namely:

a. Determination of Long-Term Plans and Strategic Plans

b. Annual meeting to prepare an empowerment strategy in a given year

c. Finalize the results of planning and socialization

d. Adjustment of education staff with the availability of assignments in the field 
"Preparation of annual plans, starting in early January, after getting DIPA, throughout the year, because if there is a change must be revised immediately (according to the statement of WD II, Prof. Yohanes).

Based on the presentation of WD II, that this planning must be done in a team, starting from the University to the Study Program, the planning team is part of a separate team whose task is to plan which must work in synergy with other units, which is considered not easy to do.

The planning phase begins with the university's Vision and Mission which has been prepared based on the Tri Dharma of Higher Education. Then the vision and mission are translated into the faculty's vision and mission. Collaboration of all parties at the university resulted in seven points formed in the Untan Chancellor Agreement to the Minister (Menristekdikti). This agreement as a goal as well as benchmarks as well as the vision and mission that must be accounted for by the rector to the Minister.

"This Performance Agreement is then translated through programs ranging from the university stage to the smallest scale in a department or study program," according to WD II. One of the points in the performance agreement is to maximize the utilization of human resources (educators and education staff) in supporting the quality and achievement of vision, one of which is the ability of human resources to manage existing facilities and infrastructure.

Then, the requirements written in the form of work programs are detailed in the form of the RKAL which was submitted two years earlier. So that at this point it takes the leadership's ability to predict needs, one of which is the need for facilities and infrastructures within the next two years.

\section{Implementation and Steps of Faculty Leaders}

The implementation of the management of education personnel in FKIP is very much tied to the methods used, namely conventional and modern methods. Based on the findings in the field, the conventional method in question is HR management using the 'old way', by controlling manual and paper-based controls. While the modern way in question is HR management that will be greatly assisted by technology and modern style work thinking. So that the implementation and monitoring of $\mathrm{HR}$ is carried out by utilizing technology, including when distributing salaries of education personnel who will use a Virtual Account (VA).

The model of monitoring the implementation of the performance of education staff in FKIP is carried out by the leadership, from the Dean, Deputy Dean, to the Head of Section. While the main person in charge of the implementation of the activities of the education staff under the coordination of the head of the section, then the head of the sub-section, and then each of the staff who are assigned according to the main tasks and functions assigned.

\section{Evaluation}

The performance evaluation system currently still uses the method commonly used in most other institutions, namely manually. The evaluation results of faculty leaders (Deans and Deputy Deans) are given to the Head of Section, then the Head of Section who will provide guidance to staff who are considered still not in accordance with their main tasks and functions. The Deputy Dean II acknowledged that at present it still uses manual evaluation and reporting, but online evaluations are being prepared.

"Soon we will implement an online system, so this is good, so we need to be careful in budgeting and utilizing facilities and infrastructure," according to Prof. Yohanes, Deputy Dean II.

This is also supported by the statement of the Head of Department, that indeed the evaluation system still uses manuals or is known as the general method that has been abandoned by most Institutions, especially higher education institutions. One of the disadvantages of a manual system is that it is less efficient and effective in carrying out evaluations that must be done. 


\section{Supporting and Inhibiting Factors}

Based on field findings, the supporting factors in the management of education personnel in managing facilities and infrastructure are:

a. Availability of internet access and utilization of technology for monitoring

b. Openness in planning to evaluation

c. The participation of all faculties in ensuring the optimization of educational staff

d. Dedication and totality of education staff, especially staff who have been assigned for more than five years in FKIP

Meanwhile, several inhibiting factors found to date include:

1. The flow of institutional planning and organization at a university that is considered too long (less simple)

2. Most monitoring and evaluation systems still use manuals, but online (modern) reporting and evaluation systems are being prepared

3. Central government policies related to the procurement of facilities and infrastructure that must be submitted a maximum of two years earlier

4. All activities need to be planned with good predictions, so that challenges for HR planning

5. The absence of performance monitoring technology, such as CCTV as a support tool for staff control in managing facilities and infrastructure.

Based on the expectations of the findings of this study, it is known that efforts to empower educational staff can be seen from at least three sides: First, creating an atmosphere or climate that enables potential employees to develop. The starting point is that every human being has the potential to be developed. That is, there are no employees who are completely helpless, because if so it will easily become extinct. Empowerment is an effort to develop that power, by encouraging, motivating and raising awareness of its potential and trying to develop it. Second, strengthen the potential or power possessed by employees. In this framework, more positive steps are needed, aside from only creating a climate and atmosphere. This strengthening includes concrete steps, and involves providing various inputs. Third, empowering also means protecting. In the empowerment process, the weak must be prevented from becoming weaker, because of lack of power in facing the strong. Protecting must be seen as an effort to prevent unbalanced competition, and strong exploitation of the weak.

Educational staff who are part of the Human Resources of an Institution have a very important position. The position of HR is also comparable or even more important when compared to material resources in the form of funding, infrastructure, and others. Therefore, based on the presentation of the results of research conducted in the field, the following will be discussed in detail about how to empower HR in this case the education staff in managing facilities and infrastructure at FKIP Tanjungpura University.

The flow of empowerment that has been carried out by FKIP leaders for educational staff in managing facilities and facilities is done with a good plan and monitoring. This is if associated with opinions (Soekanto, 1987: 63), that at least empowerment is carried out through several stages, namely

a. Preparation phase. At this stage there are two steps that must be done, namely: first, the retention of officers, namely community empowerment that can be done by community worker, and both existing field preparation is basically attempted to be carried out non-directively.

b. Stage of Assessment (assessment). At this stage, the assessment process can be carried out individually through groups in the community. In this case the officer must try to identify the problem of perceived needs (feel needs) and also the resources that the client has. 
c. Stages of alternative planning programs or activities. At this stage the officer as a change agent (exchange agent) participative tries to involve citizens to think about the problems they face and how to overcome them. In this context the community is expected to be able to think of several alternative programs and activities that can be carried out.

d. The phase of formalizing the action plan, at this stage the change agent helps each group to formulate and determine what programs and activities they will undertake to overcome existing problems. Also, officers also helped to formalize their ideas in written form, especially if they had to do with making proposals to funders.

e. Stage of implementation (implementation) of a program or activity. To implement the community empowerment program the role of the community as cadres is expected to maintain the sustainability of the programs that have been developed. Cooperation between officers and the community is important at this stage because sometimes something that has been planned well deviates from the field.

f. Evaluation phase, evaluation as a process of supervision of citizens and officers of ongoing community empowerment programs should be carried out by involving citizens. With the involvement of citizens, it is expected that in the short term it will usually form a community system for internal supervision and for the long-term can build more community communication by utilizing existing resources.

g. Termination stage. The termination phase is a formal termination of relations with the target community. In this stage, the project is expected to stop immediately.

h. Revitalization in the context of education means maximizing all the elements of education that are owned to be more vital or empowered again, so that the educational goals and processes carried out can be achieved and carried out with the maximum. national education development objectives by the mandate of Law Number 20 of 2003 concerning the national education system.

\section{Conclusions}

Based on the results of the discussion described above, it can be concluded as follows:

1. Empowerment planning is carried out by a team that has been formed to create a program based on the faculty's vision and mission

2. In implementing the empowerment of education staff the leaders coordinate, but on the other hand the methods used to optimize work are still in a conventional way.

3. Evaluation of the empowerment of education personnel is carried out still manually, including the reporting system

4. The supporting factors and barriers include; Availability of internet access and utilization of technology for monitoring, Openness in planning to evaluation, Participation of all faculties in ensuring optimization of education staff, Service and totality of education staff, especially staff who have been assigned for more than five years in FKIP.

\section{Suggestions}

1. Leaders in the Teaching and Education Faculty in empowering educational staff should also pay attention to the reward system with the intention of increasing employee morale.

2. Financing by the faculty leadership starting from the Deputy Dean II, the head of administration, the head of the equipment section to the education staff should be carried out continuously

3. The educational teams are expected to increase the intensity of their work selflessly and receive services that are following their abilities. 


\section{References}

Adam, Robert. (2003). Social Work and Empowerment. New York Palgrave: Mc Millan.

Adi, I.R. (2008). Intervensi Komunitas: Pengembangan Masyarakat. Jakarta: PT Raja grafindo Persada.

Agung, Iskandar. (2014). Pendidikan wawasan Kebangsaan di Daerah Perbatasan. Jakarta: Bee Media.

Alsop, Ruth dkk. (2006). Empowerment in Practice From Analisis to Implementation. Washington: The World Bank.

Dessler, Gary. (2013). Human Resource Management. Thirteen Edition. Boston Pearson.

Fahruddin, Adi. (2012). Pemberdayaan, Partisipasi dan Penguatan Kapasitas Masyarakat. Bandung: Humaniora.

Jones J.J., \& Walters, D.L. (2008). Human Resource Management in Education. Q. Media.

Mondros, Jacqueline, B., Scott M. Wilson. (1996). Organizing for Power and Empowerment. New York: Colombia University Press.

Mondy, Joseph R Joseph J Martocchio. (2016). Human Resource Management. Fourteenth Edition. Boston Pearson

Mulyasa, E. (2006). Menjadi Guru Profesional Menciptakan Pembelajaran Kreatif dan Menyenangkan. Bandung: Rosdakarya.

Nijiyati dkk. (2005). Pemberdayaan Masyarakat di Lahan Gambut. Proyek Climate Change.

Suharto, Edi. (2005). Membangun Masyarakat Memberdayakan Rakyat. Bandung: PT Refika Aditama.

Wrihatnolo, Nugroho. (2007). Manajemen Pemberdayaan Sebuah Pengantar dan Pemanduan untuk Pemberdayaan Masyarakat. Jakarta: PT. Elex Media Komputindo. 